\title{
Chitinase from Enterobacter sp. NRG4: Its purification, characterization and reaction pattern
}

\author{
Neetu Dahiya \\ Department of Biotechnology \\ Panjab University \\ Chandigarh, PIN-160014, India \\ Tel: 911722534150 \\ Fax: 911722541409 \\ E-mail:ineetudahiya@yahoo.com \\ Rupinder Tewari \\ Department of Biotechnology \\ Panjab University \\ Chandigarh, PIN-160014, India \\ Tel: 911722534180 \\ Fax: 911722541409 \\ E-mail:rooptt1@glide.net.in \\ Ram P. Tiwari \\ Department of Microbiology \\ Panjab University \\ Chandigarh, PIN-160014, India \\ Tel: 911722541770 \\ Fax: 911722541409 \\ E-mail: rptiwari@rediffmail.com
Gurinder Singh Hoondal*
Department of Microbiology Panjab University
Chandigarh, PIN-160014, India
Tel: 911722541770
Fax: 911722541409
E-mail:gshoondal@rediffmail.com

Financial support: Senior Research Fellowship from Council of Scientific and Industrial Research (CSIR), Government of India for Neetu Dahiya.

Keywords: chemical modification, chitinase, Enterobacter sp. NRG4, purification, substrate binding.

Enterobacter sp. NRG4 was shown to excrete chitinase into the culture supernatant when cultivated in medium containing chitin. A $60 \mathrm{kDa}$ extracellular chitinase was purified to homogeneity and characterized. The enzyme hydrolyzed swollen chitin, colloidal chitin, regenerated chitin and glycol chitin but did not hydrolyze chitosan. The chitinase exhibited $K_{m}$ and $V_{\text {max }}$ values of $1.43 \mathrm{mg}$ $\mathrm{ml}^{-1}$ and $83.33 \mu \mathrm{M} \mu \mathrm{g}^{-1} \mathrm{~h}^{-1}$ for swollen chitin, $1.41 \mathrm{mg} \mathrm{ml}^{-}$ 1 and 74.07 $\mu \mathrm{M} \mu \mathrm{g}^{-1} \mathrm{~h}^{-1}$ for colloidal chitin, $1.8 \mathrm{mg} \mathrm{ml}^{-1}$ and $40 \mu M \mu \mathrm{g}^{-1} \mathrm{~h}^{-1}$ for regenerated chitin and $2.0 \mathrm{mg} \mathrm{ml}^{-}$ 1 and $33.33 \mu \mathrm{M} \mu \mathrm{g}^{-1} \mathrm{~h}^{-1}$ for glycol chitin, respectively. The optimal temperature and $\mathrm{pH}$ for activity were $45^{\circ} \mathrm{C}$ and $\mathrm{pH}$ 5.5, respectively. $\mathrm{Mg}^{2+}, \mathrm{K}^{+}$and $\mathrm{Ca}^{2+}$ stimulated chitinase activity by 13,16 and $18 \%$, respectively whereas $\mathrm{Cu}^{2+}, \mathrm{Co}^{2+}, \mathrm{Ag}^{+}$and $\mathrm{Hg}^{2+}$ inhibited chitinase activity by $9.7,15,22$ and $72.2 \%$, respectively at $1 \mathrm{mM}$ concentration. N-bromosuccinamide (NBS) at $1 \mathrm{mM}$ and iodoacetamide at $10 \mathrm{mM}$ concentration completely inhibited the enzyme activity. Dithiobisnitrobenzoic acid (DTNB) at $10 \mathrm{mM}$ concentration inhibited chitinase activity by $97.2 \%$. Chitin was hydrolyzed to chitobiose and $\mathrm{N}$-acetyl D-glucosamine when incubated with the purified enzyme. The hydrolysis pattern of the purified enzyme indicated that the chitinase was an endochitinase.

Chitin is composed of repeating $\mathrm{N}$-acetyl D-glucosamine residues and is a component of crustacean exoskeleton, diatoms, fungal cell walls, and squid pens. Chitin is a versatile and promising biopolymer with numerous industrial, medical and commercial uses. However, it is difficult to purify and modify chemically. Hence identification of chitin modifying enzymes and elucidation of their activities could facilitate the efficient production of specific chitin products. The biodegradation of chitin requires the synergistic action of several hydrolytic enzymes

*Corresponding author 
Table 1. Purification of chitinase by ammonium sulphate, DEAE-Sephadex column chromatography and Sephadex G-200 gel filtration.

\begin{tabular}{|l|c|c|c|c|c|}
\hline \multicolumn{1}{|c|}{ Purification Step } & $\begin{array}{c}\text { Total } \\
\text { Activity } \\
(\mathbf{U})\end{array}$ & $\begin{array}{c}\text { Total } \\
\text { protein } \\
\text { (mg) }\end{array}$ & $\begin{array}{c}\text { Specific } \\
\text { activity } \\
\text { (U/mg) }\end{array}$ & Purification fold & $\begin{array}{c}\text { Recovery } \\
\text { (\%) }\end{array}$ \\
\hline Cell free supernatant & 45100 & 255 & 176.4 & - & 100 \\
\hline $\begin{array}{l}\text { Dialysed (ammonium sulphate } \\
\text { precipitation 30-75\%) }\end{array}$ & 31950 & 57 & 560.5 & 3.18 & 71.0 \\
\hline DEAE Sephadex & 22500 & 5.5 & 4090.9 & 23.2 & 47.1 \\
\hline $\begin{array}{l}\text { Gel filtration } \\
\text { (Sephadex G-200) }\end{array}$ & 14010 & 1.8 & 7783.3 & 44.12 & 31.1 \\
\hline
\end{tabular}

for efficient and complete breakdown. The combined action of endochitinases (EC 3.2.1.14) and exochitinases [(chitobiosidases and $\beta$-N-acetyl hexosaminidase (EC 3.2.1.82)] results in the degradation of chitin polymer into the soluble N-acetyl D-glucosamine (Gkargkas et al. 2004). Chitinases are produced by different micro-organisms which generally present a wide multiplicity of enzymes that are mainly extracellular. They have received increased attention due to their wide range of biotechnological applications, especially in the production of chitooligosaccharides and $\mathrm{N}$-acetyl D-glucosamine (Pichyangkura et al. 2002), biocontrol of pathogenic fungi (Chernin et al. 1997; Mathivanan et al. 1998), preparation of sphaeroplasts and protoplasts from yeast and fungal species (Mizuno et al. 1997; Balasubramanium et al. 2003) and bioconversion of chitin waste to single cell protein (Vyas and Deshpande, 1991).

In the present investigation we report an endochitinase that was purified and characterized from a newly isolated Enterobacter sp. NRG4.

\section{MATERIALS AND METHODS}

\section{Chemicals and substrates}

Flake chitin was obtained from Hi-Media, India. Swollen chitin was prepared by the method of Monreal and Reese (1969), colloidal chitin by the method of Jeuniaux (1966),

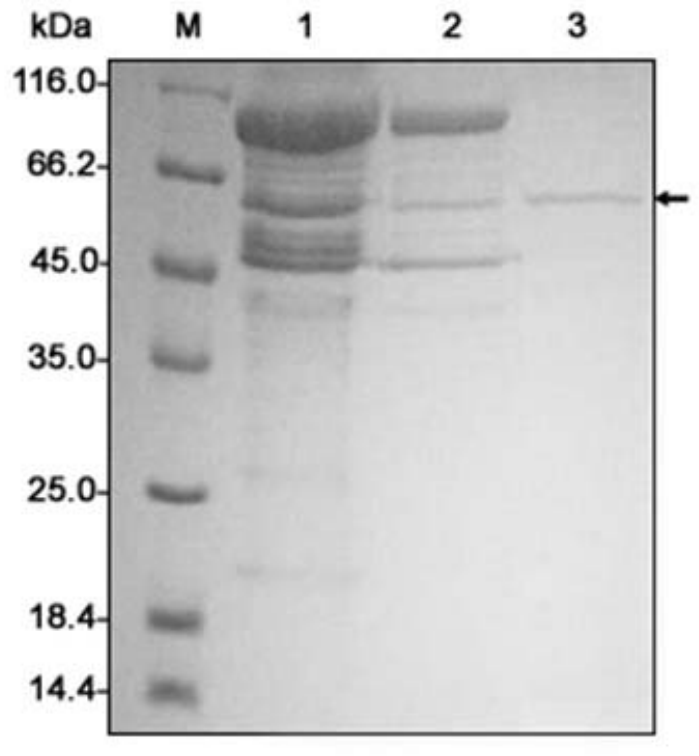

(a)

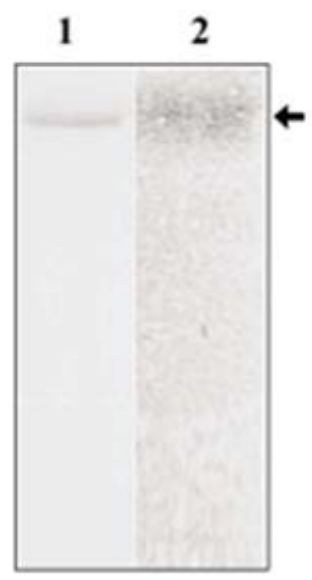

(b)

Figure 1. SDS-PAGE analysis of chitinase purified from Enterobacter sp. NRG4.

(a) Lane M, Molecular weight markers; Lane 1, Ammonium sulphate precipitated proteins (100 $\mu \mathrm{g})$; Lane 2, lon exchange purified proteins $(30 \mu \mathrm{g})$; Lane 3, Sephadex G-200 purified chitinase $(6 \mu \mathrm{g})$.

(b) Lane 1, Native-PAGE; Lane 2, Zymogram of purified chitinase of Enterobacter sp. NRG4. 

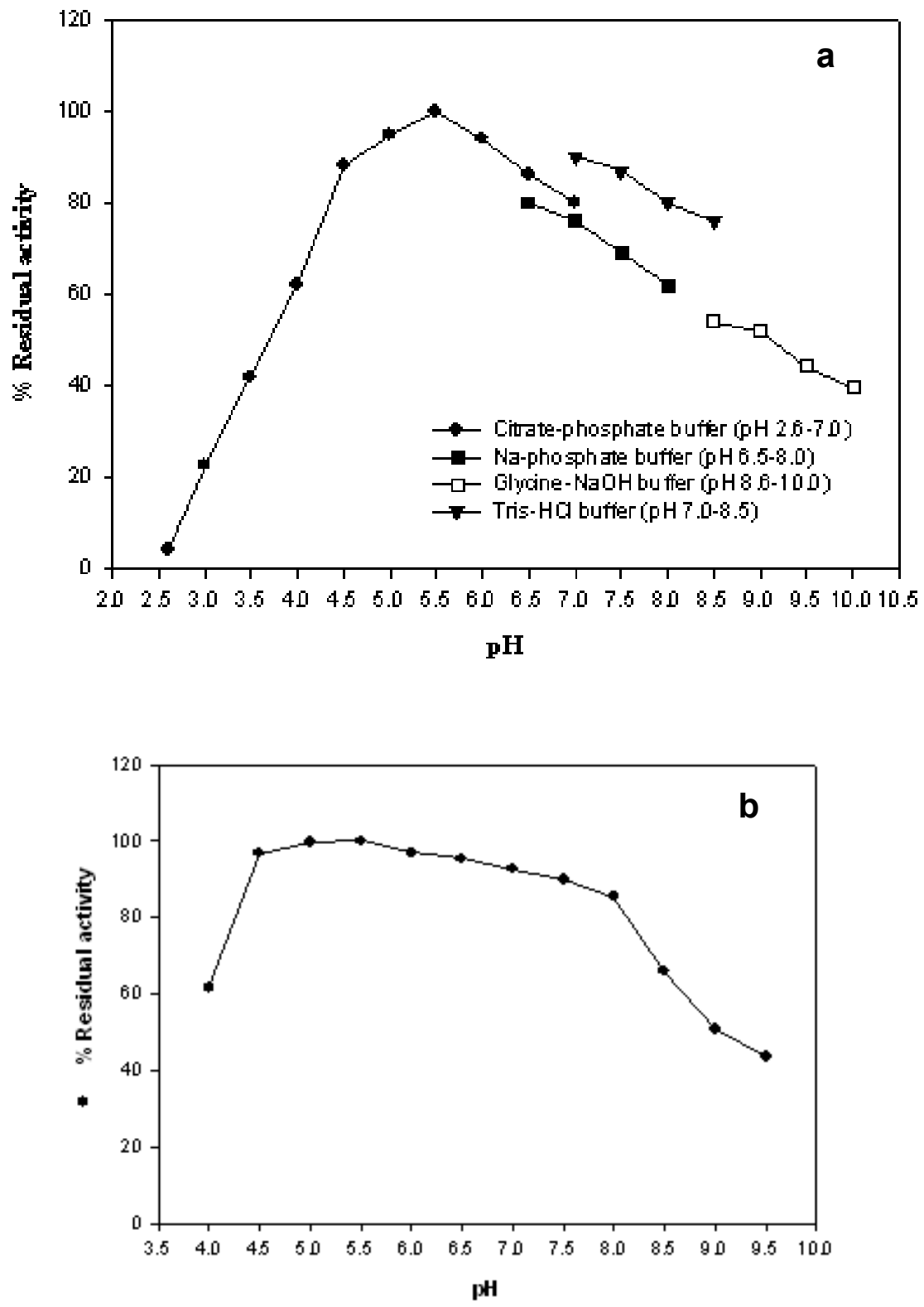

Figure 2.

(a) Effect of assay $\mathrm{pH}$ on purified chitinase activity.

(b) $\mathrm{pH}$ stability profile of purified chitinase from Enterobacter sp. NRG4.

regenerated chitin by the method of Molano et al. (1977) and glycol chitin by the method of Yamada and Imoto (1981). N-acetyl D-glucosamine was obtained from Fluka and chitobiose from Sigma, Co. All other reagents used were of analytical grade.

\section{Micro-organism and culture conditions}

Enterobacter sp. NRG4 isolated from degraded stalk of mushroom was selected as a potent chitinase producer (Dahiya et al. 2005). The culture medium was composed of $1.0 \%$ swollen chitin, $0.5 \%$ peptone, $0.5 \%$ yeast extract,
$0.1 \% \mathrm{KH}_{2} \mathrm{PO}_{4}$ and $0.01 \% \mathrm{MgSO}_{4} .7 \mathrm{H}_{2} \mathrm{O}(\mathrm{pH}$ 8.0). The micro-organism was cultivated at $30^{\circ} \mathrm{C}$ for $72 \mathrm{hrs}$ with agitation at $150 \mathrm{rpm}$.

\section{Enzyme and protein assay}

The assay mixture contained $1 \mathrm{ml}$ swollen chitin and $0.5 \mathrm{ml}$ enzyme solution. After incubation at $45^{\circ} \mathrm{C}$ for $15 \mathrm{~min}$, it was centrifuged at $5000 \times \mathrm{g}$ for $10 \mathrm{~min}$. The amount of $\mathrm{N}$ acetyl D-glucosamine released in the supernatant was determined by the method of Reissig et al. (1955), using Nacetyl D-glucosamine as the standard. One enzyme unit 
Table 2. Kinetic parameters for chitin hydrolysis by Enterobacter sp. NRG4 chitinase.

\begin{tabular}{|l|c|c|}
\hline $\begin{array}{c}\text { Substrate } \\
(\mathbf{1 . 0 \% )}\end{array}$ & $\begin{array}{c}\mathbf{K}_{\mathrm{m}} \\
\left(\mathrm{mg} \mathrm{ml}^{-1}\right)\end{array}$ & $\begin{array}{c}\mathbf{V}_{\max } \\
\left(\boldsymbol{\mu m o l e ~} \mathbf{\mu g}^{-1} \mathbf{h}^{-1}\right)\end{array}$ \\
\hline Swollen chitin & 1.43 & 83.33 \\
\hline Colloidal chitin & 1.41 & 74.07 \\
\hline Regenerated chitin & 1.8 & 40.00 \\
\hline Glycol chitin & 2.0 & 33.33 \\
\hline
\end{tabular}

was defined as the amount of enzyme that catalyzes the release of $1 \mu \mathrm{mol}$ of $\mathrm{N}$-acetyl D-glucosamine in $1 \mathrm{hr}$ at $45^{\circ} \mathrm{C}$.

The protein concentration was measured using the method of Lowry et al. (1951) with bovine serum albumin as standard. For the purified enzyme, protein concentration was measured by determining the absorbance at $280 \mathrm{~nm}$.

\section{Purification of chitinase}

The purification of chitinase was carried out in three steps. The cell free supernatant was precipitated with 30\% ammonium sulphate. The resultant precipitate was centrifuged at $10,000 \times \mathrm{g}, 4^{\circ} \mathrm{C}$. Then ammonium sulphate concentration was increased to $75 \%$ saturation and it was left overnight at $4^{\circ} \mathrm{C}$. The precipitate was collected by centrifugation at $10,000 \times \mathrm{g}, 4^{\circ} \mathrm{C}$. It was dissolved in $50 \mathrm{ml}$ of $25 \mathrm{mM}$ Tris- $\mathrm{HCl}$ buffer $\mathrm{pH} 7.5$ and dialysed against the same buffer.

The dialysed protein was subjected to ion exchanger, DEAE-Sephadex column $(1.5 \times 12 \mathrm{~cm})$. The adsorbed chitinase was eluted by a linear gradient of $\mathrm{NaCl}$ from 0 to $0.25 \mathrm{M}$ in the same buffer. Chitinase activity was assayed in each $5.0 \mathrm{ml}$ fraction at a flow rate of $42 \mathrm{ml} \mathrm{h}^{-1}$. In final step, the active fractions were pooled, concentrated by polyethylene glycol and dialysed against Tris- $\mathrm{HCl}, \mathrm{pH} 7.5$ and loaded onto a gel filtration column $(2.2 \mathrm{~cm} \times 90 \mathrm{~cm})$, Sephadex G-200 and flow rate was maintained at $20 \mathrm{ml} \mathrm{h}-$ 1. The molecular weight was estimated from a standard curve obtained from the proteins with their molecular weights known (68 kDa, bovine serum albumin, $45 \mathrm{kDa}$, ovalalbumin and $30 \mathrm{kDa}$, casein).

The purified protein was loaded onto SDS-PAGE (12\%) as described by Laemmli (1970) to determine the protein profile. Native PAGE was carried out with the aim to study the zymography pattern of chitinase. The detailed procedure was exactly similar to the SDS-PAGE in which SDS, mercaptoethanol and the heating step during protein sample preparation were eliminated. The native PAGE gel was run with purified chitinase preparation. Half of the gel was cut and stained to locate the position of single band and the other half of the gel was placed over chitin agar plate $(1.0 \%$ swollen chitin in citrate phosphate buffer $+1.5 \%$ agar) and incubated overnight at $45^{\circ} \mathrm{C}$ to find the zone of clearance.

\section{Characterization of purified chitinase}

The purified chitinase was characterized with respect to its optimum $\mathrm{pH}$, temperature, stability at different temperatures and $\mathrm{pH}$ values, effect of metal ions, surfactants, organic solvents on activity and stability.

Chitinase activity was assayed at different $\mathrm{pH}$ values $(\mathrm{pH}$ 2.6 to 10.0 ) using different buffers $50 \mathrm{mM}$ such as citratephosphate buffer $(\mathrm{pH}, 2.6-7.0)$, sodium phosphate buffer $(\mathrm{pH}, 6.5-8.0)$, tris- $\mathrm{HCl}$ buffer $(\mathrm{pH}, 7.0-8.5)$ and glycine$\mathrm{NaOH}$ buffer $(\mathrm{pH}, 8.6-10.0)$. To determine $\mathrm{pH}$ stability, chitinase preparations in buffer at different $\mathrm{pH}$ ranging from 4.0-9.0 were kept at room temperature for $2 \mathrm{hrs}$. Thereafter chitinase activity was assayed under standard conditions.

Chitinase activity was assayed at different temperatures ranging from $35-60^{\circ} \mathrm{C}$ at $\mathrm{pH} 5.5$ in citrate phosphate buffer $(50 \mathrm{mM})$. To determine thermostability, chitinase preparation was incubated at temperature ranging from 40 $55^{\circ} \mathrm{C}$ for different time intervals up to $3 \mathrm{hrs}$. Chitinase activity was assayed at $45^{\circ} \mathrm{C}$ and $\mathrm{pH} 5.5$.

The effect of substrate concentration on chitinase activity was determined at different concentrations of chitin, varying between $0.25 \mathrm{mg} \mathrm{ml}^{-1}$ to $16 \mathrm{mg} \mathrm{ml}^{-1}$ (w/v). The $\mathrm{K}_{\mathrm{m}}$ and $\mathrm{V}_{\max }$ values were determined by Lineweaver-Burk's plot.

The effect of metal ions on enzyme activity was studied by incorporating these metal ions such as $\mathrm{MgSO}_{4} \cdot 7 \mathrm{H}_{2} \mathrm{O}, \mathrm{KCl}$, $\mathrm{CaCl}_{2}, 2 \mathrm{H}_{2} \mathrm{O}, \mathrm{CuCl}_{2}, 2 \mathrm{H}_{2} \mathrm{O}, \mathrm{HgCl}_{2}, \mathrm{AgNO}_{3}, \mathrm{CoCl}_{2}, 2 \mathrm{H}_{2} \mathrm{O}$, $\mathrm{ZnSO}_{4}, \mathrm{FeCl}_{3}$ and $\mathrm{FeSO}_{4}$ in reaction mixture at $1 \mathrm{mM}$ to 100 $\mathrm{mM}$ concentration. Effects of these metal ions on enzyme stability were studied by incubating the purified enzyme in $25 \mathrm{mM}$ Tris-HCl buffer, $\mathrm{pH} 7.5$, with these metal ion salts at room temperature for $1 \mathrm{hr}$ and subsequently determining the residual enzyme activity under standard assay conditions.

Allosamidin was added to the enzyme solution in the concentration range from 1 to $100 \mu \mathrm{g} \mathrm{ml}^{-1}$ and incubated at room temperature for $1 \mathrm{hr}$. Thereafter, residual enzyme activity was determined under standard assay conditions. The effect of sugars such as $\mathrm{N}$-acetyl D-glucosamine, glucosamine $\mathrm{HCl}$, galactosamine and glucose was studied by incorporating these sugars at $1 \mathrm{mM}$ and $10 \mathrm{mM}$ concentration in the reaction mixture and subsequently determining the enzyme activity.

Substrate binding was determined by incubating the enzyme with $10 \mathrm{mg}$ substrate in citrate phosphate buffer $(50 \mathrm{mM}, \mathrm{pH} 5.5)$ for $30 \mathrm{~min}$ at $0^{\circ} \mathrm{C}$ with intermittent 
shaking followed by centrifugation at $4^{\circ} \mathrm{C}$ and residual activity was determined in the supernatant under standard assay conditions.

Chemical modification of chitinase was done using several reagents such as para chloromecuribenzoate (PCMB), Nbromosuccinimide (NBS), 5, 5'-dithiobis-(2-nitrobenzoic) acid (DTNB), iodoacetamide and methylene blue. The effects of these modifiers were tested by incubating the enzyme with varying concentrations $(0.1 \mathrm{mM}$ to $10 \mathrm{mM})$ of the modifiers in the reaction mixture.

\section{Hydrolysis pattern of purified chitinase}

The mode of action of chitinase was determined by viscometric assay (Otakara, 1961). Purified chitinase (60 $\mu \mathrm{g})$ was added to $60 \mathrm{ml}$ substrate solution $\left(5 \mathrm{~g} \mathrm{~L}^{-1}\right.$ glycol chitin in $50 \mathrm{mM}$ citrate phosphate buffer, $\mathrm{pH}, 5.5)$ and the mixture was incubated at $45^{\circ} \mathrm{C}$ for digestion. Aliquots $(10$ $\mathrm{ml}$ each) were removed at intervals and subjected immediately to viscosity measurement on an Ostwald viscometer. After incubation of the enzyme with $1.0 \%$ swollen chitin at $45^{\circ} \mathrm{C}$ for $5 \mathrm{hrs}$, the hydrolytic products of chitin were resolved by high performance liquid chromatography (HPLC) (Shimadzu, USA). The HPLC system was fitted with LC1oAT HPLC pumps and a SPDM10A detector. A reversed phase $100 \mathrm{NH}_{2}(4 \times 250 \mathrm{~mm})$ column from Shimadzu was used. The samples were eluted with $75 \%(\mathrm{v} / \mathrm{v})$ aceton 1 itrile in water with a flow rate of 1.0 $\mathrm{ml} \mathrm{min}{ }^{-1}$, and the injection volume was $20 \mu \mathrm{l}$. The aliquots
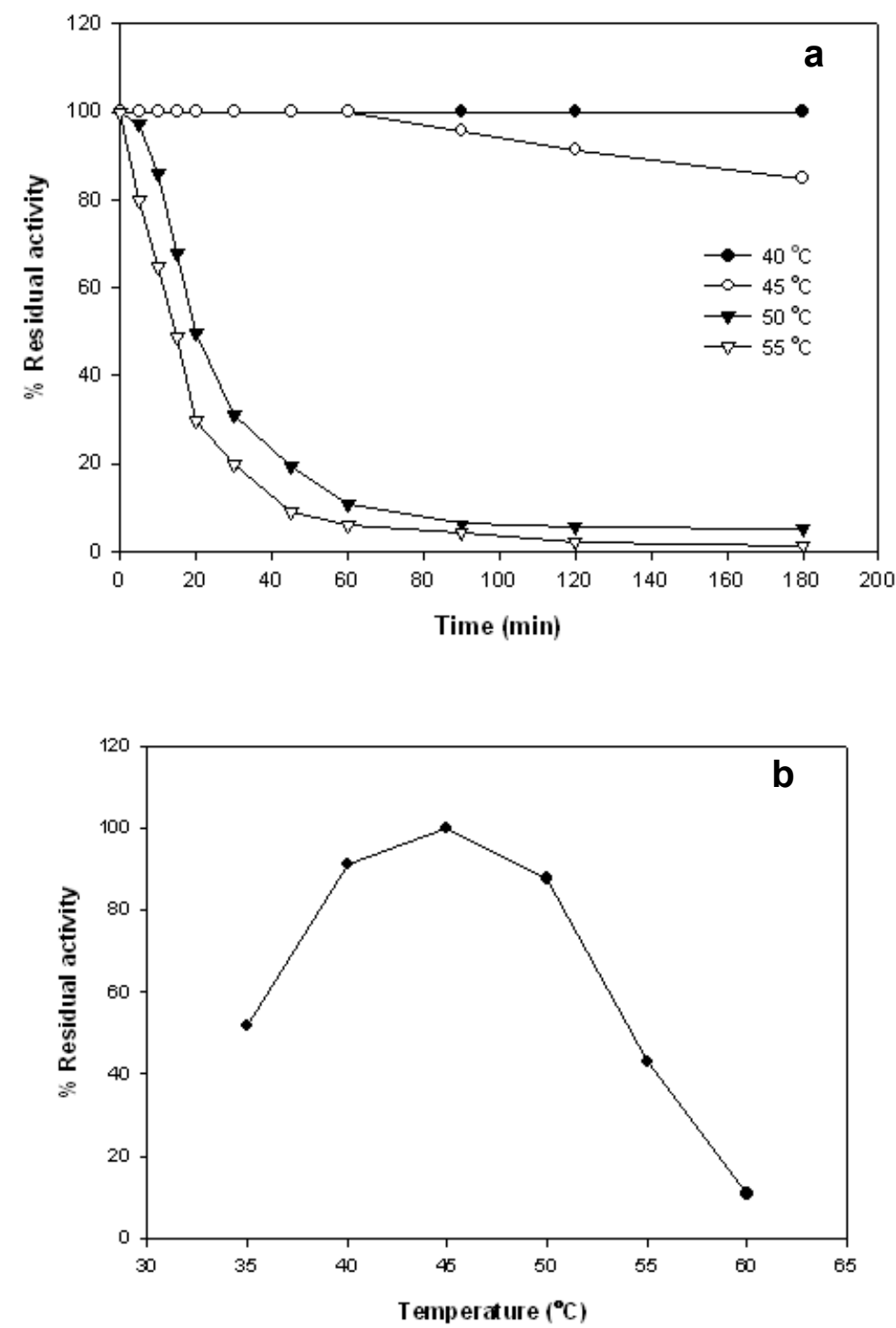

Figure 3.

(a) Effect of assay temperature on purified chitinase activity.

(b) Thermostability profile of purified chitinase from Enterobacter sp. NRG4. 
were monitored for UV absorbance at $205 \mathrm{~nm}$. N-acetyl Dglucosamine and chitobiose were used as standards. The peak areas of standard solutions and hydrolyzates were integrated by SPD-MXA real time software (Shimadzu, USA).

\section{RESULTS}

\section{Purification of chitinase}

With swollen chitin as the sole source of carbon, Enterobacter sp. NRG4 produced chitinase in the culture medium. The chitinase was purified using standard techniques i.e. ammonium sulphate precipitation $(30-75 \%)$, DEAE-Sephadex ion exchange chromatography and Sephadex G-200 gel filtration chromatography. When cell free supernatant was subjected to fractional ammonium sulphate precipitation, chitinase activity was precipitated in $30-75 \%$ salt saturation. The yield of chitinase was $71 \%$ with a purification fold of 3.18 and specific activity of $560.5 \mathrm{U} \mathrm{mg}^{-1}$ protein. The dialyzed protein was loaded on DEAE ion exchanger. After elution with 0 to $250 \mathrm{mM} \mathrm{NaCl}$ gradient two major peaks of proteins were observed but chitinase activity was observed only in peak A. Here the yield of chitinase was $47.1 \%$ with a purification fold of 23.2 and specific activity $4090.9 \mathrm{U} \mathrm{mg}^{-1}$. Using gel filtration, the chitinase was purified by 44.12 fold with specific activity of $7783.3 \mathrm{U} \mathrm{mg}^{-1}$ and the yield was $31.1 \%$. The results of chitinase purification are summarized in Table 1. The molecular weight of the chitinase was estimated to be $60 \mathrm{kDa}$ by SDS-PAGE (Figure 1a). It was consistent with the molecular mass determined by Sephadex G 200 gel filtration, suggesting that the purified chitinase is a monomer type. Native gel electrophoresis showed a single band which corresponded to chitinase activity as shown by the hydrolysis zone in the zymogram (Figure 1b).

\section{Characterization of purified chitinase}

The chitinase was maximally active at $\mathrm{pH} 4.5$ to 8.0 thus exhibiting a broad $\mathrm{pH}$ optima (Figure 2a). Determination of $\mathrm{pH}$ stability of the chitinase indicated that the enzyme was stable between $\mathrm{pH} 4.5$ to 8.0 and it retained $90 \%$ of its activity in this range (Figure $2 b$ ). The purified enzyme showed its maximum activity at $45^{\circ} \mathrm{C}$ and was stable at $40^{\circ} \mathrm{C}$ for $3 \mathrm{hrs}$ (Figure 3 ).

With acid swollen chitin, colloidal chitin, regenerated chitin and glycol chitin the purified chitinase gave $\mathrm{K}_{\mathrm{m}}$ of $1.43 \mathrm{mg}$ $\mathrm{ml}^{-1}, 1.41 \mathrm{mg} \mathrm{ml}^{-1}, 1.8 \mathrm{mg} \mathrm{ml}^{-1}$ and $2.0 \mathrm{mg} \mathrm{ml}^{-1}$, respectively and $\mathrm{V}_{\max }$ were $83.33 \mu$ mole $\mu \mathrm{g}^{-1} \mathrm{~h}^{-1}, 74.07$ $\mu$ mole $\mu \mathrm{g}^{-1} \mathrm{~h}^{-1}, 40.00 \mu$ mole $\mu \mathrm{g}^{-1} \mathrm{~h}^{-1}$ and $33.33 \mu$ mole $\mu \mathrm{g}^{-1}$ $\mathrm{h}^{-1}$, respectively (Table 2 ).

The enzyme showed activities towards swollen chitin, colloidal chitin, glycol chitin and regenerated chitin but exhibited no activity towards carboxymethyl cellulose, chitosan and Micrococcus lysodeikticus cell wall. When swollen chitin was used as substrate the activity was taken as 100. The activities with colloidal chitin, regenerated chitins, glycol chitin, flake chitin and crab shell chitin were 80.3, 44.7, 39.4, 5.9 and 2.3\%, respectively. Enterobacter sp. NRG4 chitinase reduced the viscosity of glycol chitin significantly in 5 min due to cleavage of chitin long chains by the chitinase at $45^{\circ} \mathrm{C}$ (Figure 4). Thus it was concluded

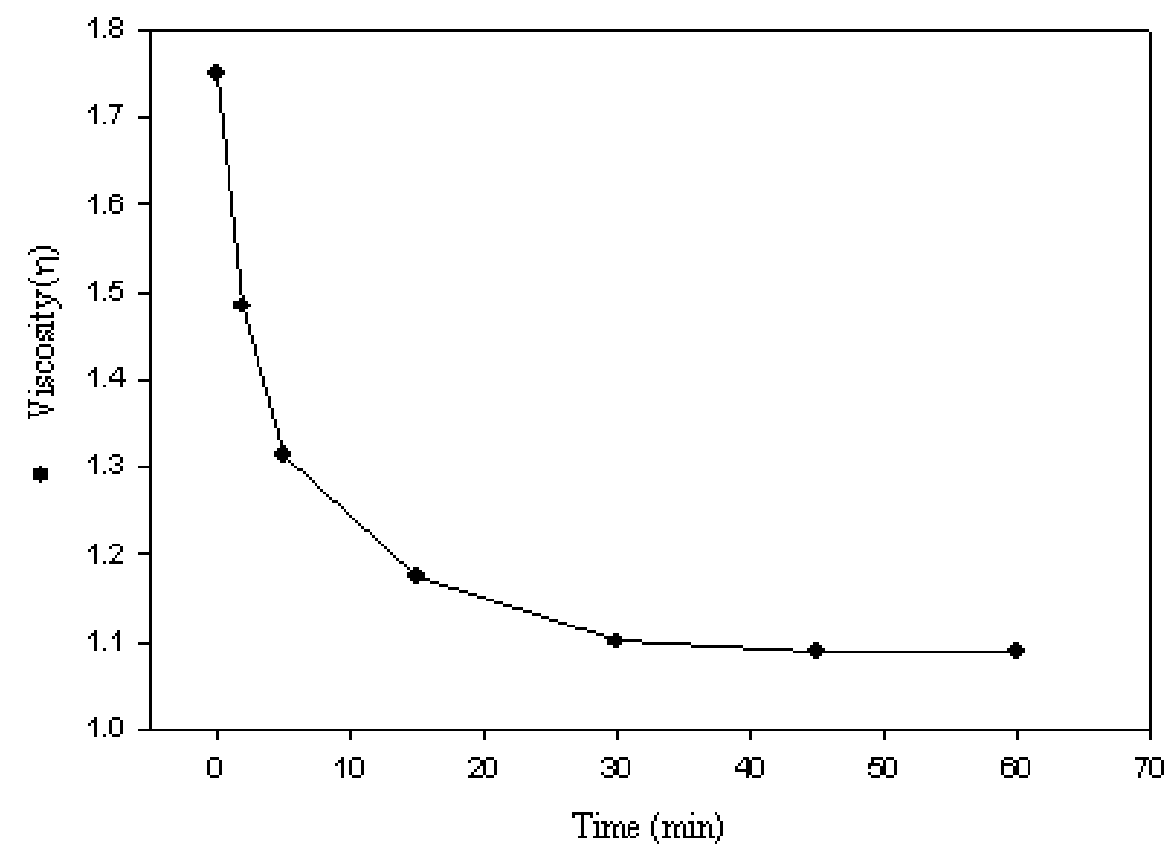

Figure 4. Hydrolysis of glycol chitin by purified chitinase. 
Table 3. Comparison of the characteristics of purified chitinase from other reported Enterobacter sp.

\begin{tabular}{|c|c|c|c|c|c|c|c|c|}
\hline Species & Chitinase & $\begin{array}{l}\text { Mol. } \\
\text { wt. } \\
\text { (kDa) }\end{array}$ & $\begin{array}{c}\text { Optimum } \\
\mathrm{pH}\end{array}$ & $\begin{array}{l}\text { Optimum } \\
\text { temp. } \\
\left({ }^{\circ} \mathrm{C}\right)\end{array}$ & Substrate & $\begin{array}{l}\text { Hydrolysis } \\
\text { product/s }\end{array}$ & Inhibitors & Reference \\
\hline $\begin{array}{c}\text { Enterobacter } \\
\text { sp. NRG4 }\end{array}$ & Endochitinase & 60 & 5.5 & 45 & $\begin{array}{l}\text { Swollen } \\
\text { chitin }\end{array}$ & $\begin{array}{l}(\mathrm{GlcNAc}) \\
(\mathrm{GlcNAc})_{2}\end{array}$ & $\begin{array}{c}\mathrm{Cu}^{2+}, \mathrm{Co}^{2+}, \mathrm{Ag}^{+}, \mathrm{Hg}^{2+}, \\
\text { NBS, DTNB } \\
\text { iodoacetamide }\end{array}$ & $\begin{array}{l}\text { Present } \\
\text { study }\end{array}$ \\
\hline $\begin{array}{c}\text { Enterobacte } \\
\text { sp. G-1 }\end{array}$ & Endochitinase & 60 & 7.0 & 40 & $\begin{array}{l}\text { Colloidal } \\
\text { chitin }\end{array}$ & $\begin{array}{l}(\mathrm{GlcNAc})_{2} \\
(\mathrm{GlcNAc})_{3} \\
(\mathrm{GlcNAc})_{4}\end{array}$ & EDTA, PCMB & $\begin{array}{c}\text { Park et al. } \\
1992\end{array}$ \\
\hline $\begin{array}{c}\text { Enterobacter } \\
\text { aerogenes }\end{array}$ & N.D. & 42.5 & 6.0 & 55 & - & - & $\mathrm{Hg}^{2+}, \mathrm{Co}^{2+} \mathrm{Mg}^{2+}$ & $\begin{array}{c}\text { Tang et al. } \\
2001\end{array}$ \\
\hline $\begin{array}{l}\text { Enterobacter } \\
\text { agglomerans }\end{array}$ & Endochitinase & 61 & 6.5 & 40 & $\begin{array}{c}\text { pNP- } \\
(\mathrm{GlcNAc})_{3}\end{array}$ & $\mathrm{pNP}$ & - & $\begin{array}{l}\text { Chernin et } \\
\text { al. } 1997\end{array}$ \\
\hline
\end{tabular}

that the purified chitinase has endo-splitting activity. As shown in Figure 5 hydrolyzed products of enzymatic reaction of purified enzyme were $(\mathrm{GlcNAc})_{2}$ and $\mathrm{N}$-acetyl D-glucosamine.

Chitinase exhibited a substrate binding capacity of 89.5 , 26.2 and $15.2 \%$ for swollen chitin, flake chitin and carboxymethyl cellulose, respectively whereas no significant substrate binding was observed for pectin, starch, xylan, wheat bran and chitosan (Figure 6).

$\mathrm{Mg}^{2+}, \mathrm{K}^{+}$and $\mathrm{Ca}^{2+}$ stimulated chitinase activity by 13,16 and $18 \%$, respectively whereas $\mathrm{Cu}^{2+}, \mathrm{Co}^{2+}, \mathrm{Ag}^{+}$and $\mathrm{Hg}^{2+}$ inhibited chitinase activity by $9.7,15,22$ and $72.2 \%$, respectively at $1 \mathrm{mM}$ concentration. At $100 \mathrm{mM}$ concentration $\mathrm{Cu}^{2+}, \mathrm{Ag}^{+}$and $\mathrm{Hg}^{2+}$ completely inhibited chitinase activity when incubated at room temperature for 1 hr whereas $\mathrm{Zn}^{2+}, \mathrm{Fe}^{3+}, \mathrm{Co}^{2+}$ and $\mathrm{Fe}^{2+}$ inhibited chitinase activity by $98.3,90.0,89.5$ and $83.7 \%$, respectively.

Allosamidin, a known specific inhibitor of chitinase inhibited Enterobacter sp. NRG4 chitinase by 57.1 and $65.7 \%$ at a concentration of 50 and $100 \mu \mathrm{g} \mathrm{ml}{ }^{-1}$, respectively, with an $\mathrm{IC}_{50}$ value of $40 \mu \mathrm{g} \mathrm{ml}^{-1}(64 \mu \mathrm{M})$ (Figure 7). Study of end-products and sugars on chitinase activity showed that $\mathrm{N}$-acetyl D-glucosamine, glucosamine $\mathrm{HCl}$, galactosamine and glucose inhibited enzyme activity by $10,8,4$ and $9.1 \%$ at $1 \mathrm{mM}$ concentration and by 81.3 , $19.0,26.0$ and $19.0 \%$, respectively at $10 \mathrm{mM}$ concentration of these sugars.

Iodoacetamide inhibited chitinase activity by $17.6,66.2$ and $84.5 \%$, respectively at $0.1 \mathrm{mM}, 1 \mathrm{mM}$ and $5 \mathrm{mM}$ concentration. DTNB inhibited chitinase activity by 1.5 , 30.6, 77.5 and $97.2 \%$, respectively at $0.1 \mathrm{mM}, 1 \mathrm{mM}, 5$ $\mathrm{mM}$ and $10 \mathrm{mM}$ concentration, respectively. NBS at $1 \mathrm{mM}$ and iodoacetamide at $10 \mathrm{mM}$ concentration completely inhibited the enzyme activity. PCMB did not affect the enzyme activity significantly. EDTA at $1 \mathrm{mM}$ concentration inhibited chitinase activity by $11 \%$.

\section{DISCUSSION}

An extracellular chitinase secreted by Enterobacter sp. NRG4 was purified to homogeneity by combination of ammonium sulphate precipitation, DEAE Sephadex ion exchange chromatography and Sephadex G-200 gel flitration chromatography. The chitinase showed a single band on $12 \%$ SDS-PAGE and Native PAGE indicating the complete purification of the enzyme. The molecular weight of the protein was found to be about $60 \mathrm{kDa}$ by SDS-PAGE as well as by gel filtration chromatography. The chitinase from Enterobacter sp. NRG4 was active over broad $\mathrm{pH}$ range i.e. from $\mathrm{pH}$ 4.5-8.0, optimum being 5.5. Several workers have reported broad $\mathrm{pH}$ optima like $\mathrm{pH}$ 4.5-7.5 of chitinase from Bacillus cereus (Pleban et al. 1997), pH 5.08.0 for Aeromonas hydrophila H-2330 (Hiraga et al. 1997), pH 7.5-9.0 for Bacillus sp. BG-11 (Bhushan and Hoondal, 1998). The $\mathrm{pH}$ optima for other chitinases reported were $\mathrm{pH}$ 4.0 for Aeromonas sp. No. 10S-24 (Ueda et al. 1995), pH 5.0 for Alcaligenes xylosoxydans (Vaidya et al. 2001) and Arthrobacter sp. NHB-10 (Okazaki et al. 1999), pH 5.5 for Bacillus sp. WY22 (Woo and Park, 2003), pH 6.0 for Enterobacter sp. G-1 (Park et al. 1997), pH 5.4 and 6.6 for CHIT60 and CHIT100, respectively from Serratia plymuthica HRO-C48 (Frankowski et al. 2001), pH 6.3 for Bacillus sp. NCTU2 (Wen et al. 2002), pH 6.5 for Vibrio alginolyticus H-8 (Ohishi et al. 1996) and Vibrio sp. (Zhou et al. 1999), pH 7.0 for Monascus purpureus (Wang et al. 2002), pH 7.0-8.0 for Bacillus 13.26 (Yuli et al. 2004) and $\mathrm{pH} 10.0$ for Cellulomonas flavigena NTOU1 (Chen et al. 1997).

The chitinase from the present strain was stable over wide $\mathrm{pH}$ range i.e. from $\mathrm{pH} 4.5$ to 8.0. Other bacterial chitinase stable over broad $\mathrm{pH}$ range were $\mathrm{pH} 4.0$ to 9.0 of Aeromonas sp. No. 10S-24 chitinase (Ueda et al. 1995), pH 6.0 to 9.0 of Pseudomonas aeruginosa K-187 (Wang and Chang, 1997), pH 5.0 to 8.0 of Aeromonas hydrophila H2330 chitinase (Hiraga et al. 1997), pH 4.0 to 9.0 for Vibrio sp. (Zhou et al. 1999), pH 6.8 to 8.0 of Bacillus sp. NCTU2 (Wen et al. 2002) chitinase and pH 4.0 to 8.5 of Bacillus cereus strain 65 (Pleban et al. 1997). 
The temperature activity and stability profile of Enterobacter sp. NRG4 chitinase revealed that the enzyme was optimally active at $45^{\circ} \mathrm{C}$. It was stable at $40^{\circ} \mathrm{C}$ for more than $3 \mathrm{hrs}$ and for $1 \mathrm{hr}$ at $45^{\circ} \mathrm{C}$. It retained $84.4 \%$ activity after $3 \mathrm{hrs}$ at $45^{\circ} \mathrm{C}$. The temperature optima of Enterobacter sp. NRG4 was in accordance with other reports in literature such as Arthrobacter sp. NHBN-10 (Okazaki et al. 1999), Vibrio alginolyticus TK-22 (Ohishi et al. 1996). Chitinase from Vibrio alginolyticus TK-22 was stable at $40^{\circ} \mathrm{C}$ for 30 min (Ohishi et al. 1996) and purified chitinase of Vibrio sp. P-6-1 was stable at $40^{\circ} \mathrm{C}$ but completely inactivated at $55^{\circ} \mathrm{C}$ in $30 \mathrm{~min}$ (Takahashi et al. 1993).

The $\mathrm{K}_{\mathrm{m}}$ values of the Enterobacter sp. NRG4 chitinase against different substrates were $1.43 \mathrm{mg} \mathrm{ml}^{-1}, 1.41 \mathrm{mg} \mathrm{ml}^{-}$
1, $1.8 \mathrm{mg} \mathrm{ml}^{-1}$ and $2.0 \mathrm{mg} \mathrm{ml}^{-1}$, respectively with swollen chitin, colloidal chitin, regenerated chitin and glycol chitin respectively, which are comparatively lower than the other reports in literature. The $\mathrm{K}_{\mathrm{m}}$ values of chitinase from different organisms were, $2.88 \mathrm{mg} \mathrm{ml}^{-1}$ for Enterobacter aerogenes (Tang et al. 2001), $1.4 \mathrm{mg} \mathrm{ml}^{-1}$ and $0.8 \mathrm{mg} \mathrm{ml}^{-1}$ for chitinase $\mathrm{C} 1$ and $\mathrm{C} 3$ from Vibrio alginolyticus $\mathrm{H}-8$ against squid chitin (Ohishi et al. 1996), $3.0 \mathrm{mg} \mathrm{ml}^{-1}$ for Alcaligenes xylosoxydans chitinase (Vaidya et al. 2003) and Bacillus sp. WY22 chitinase (Woo and Park, 2003), $12 \mathrm{mg}$ $\mathrm{ml}^{-1}$ for Bacillus sp. BG-11 chitinase (Bhushan and Hoondal, 1998).

Ethylene glycol chitin, glycol chitin and colloidal chitin are useful substrate for enzyme assays of endo-type chitinase
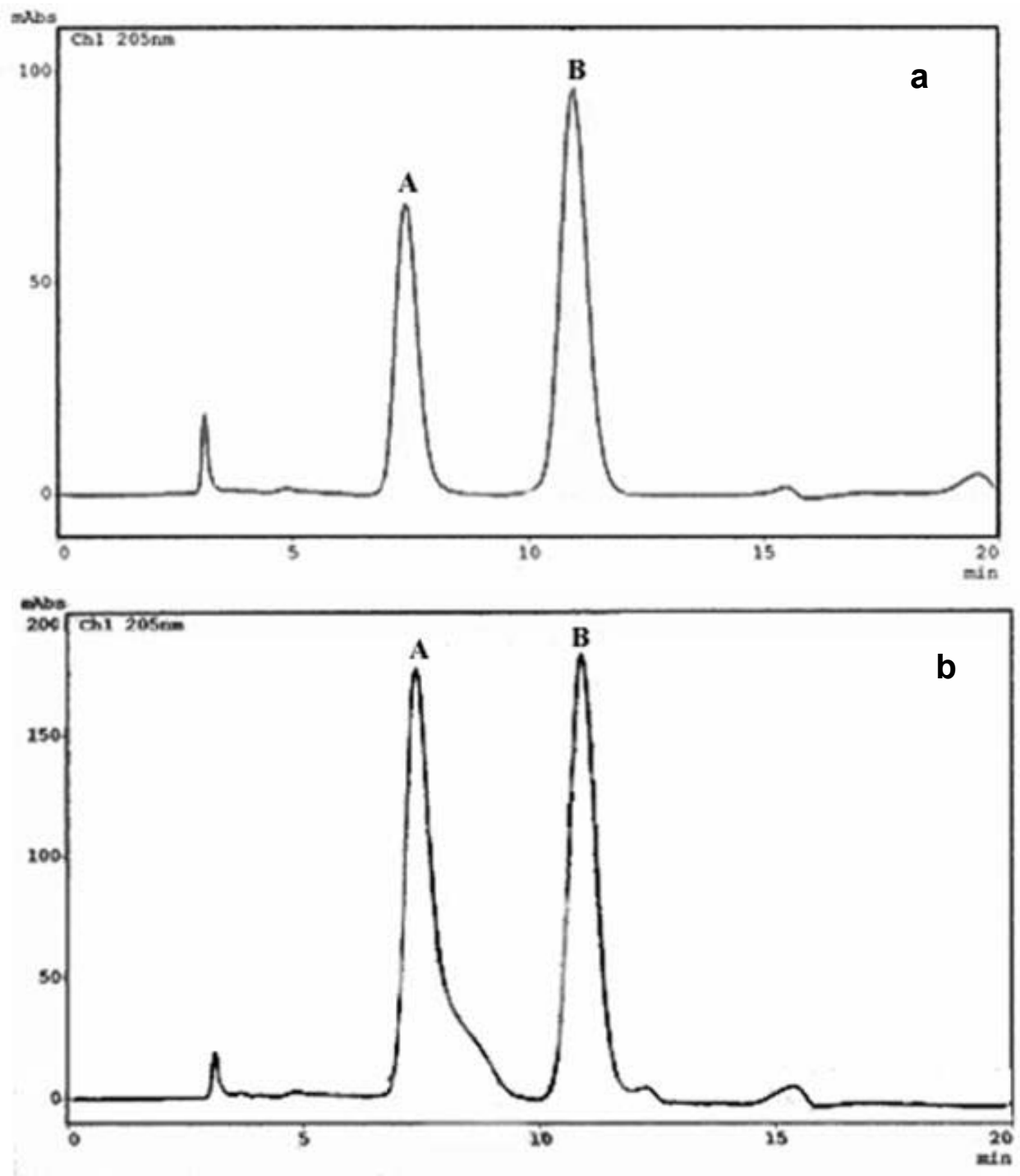

Figure 5. High Performance Liquid Chromatography of hydrolysis product/s of chitin by purified chitinase of Enterobacter sp. NRG4.

(a) Standards: A. N-acetyl D-glucosamine, B. chitobiose.

(b) Hydrolysed product/s of chitin after 5 hrs of enzyme-substrate reaction $\left(1.0 \%\right.$ swollen chitin $+10 \mathrm{U} \mathrm{ml}^{-1}$ chitinase). 


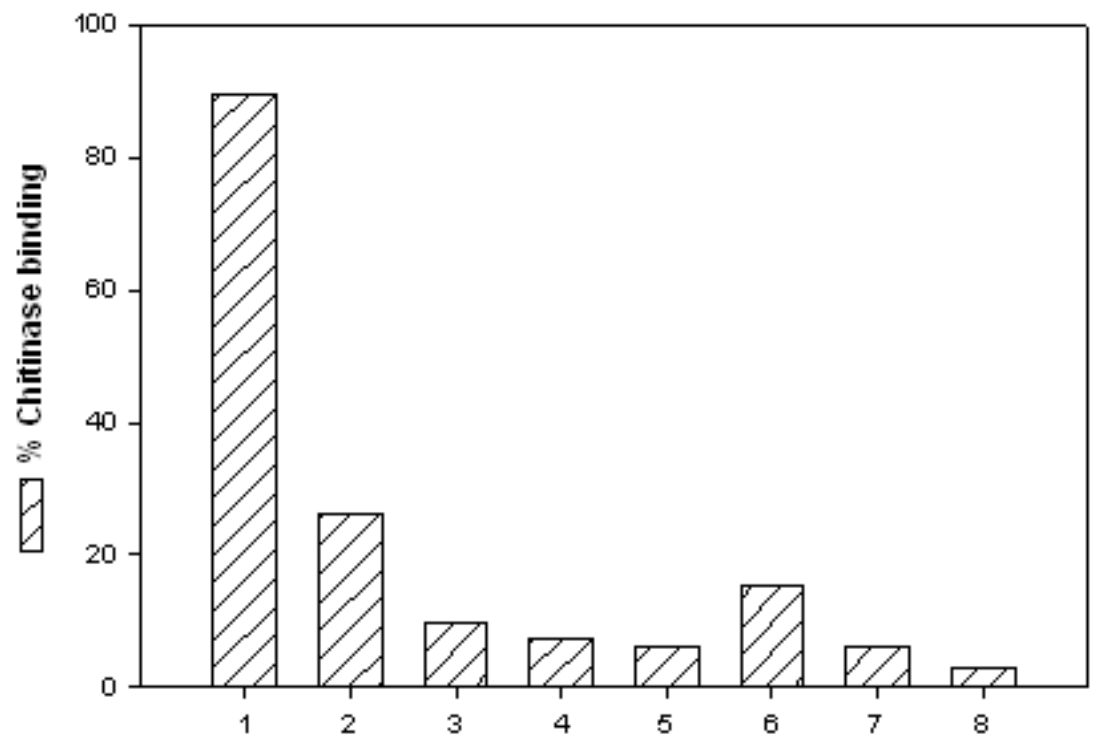

Figure 6. Substrate binding profile of chitinase at $\mathbf{C}$ for $\mathbf{h}$. 1, Swollen chitin; 2, Flake chitin; 3, Wheat bran; 4, Chitosan; 5, Pectin; 6, Carboxymethyl cellulose; 7, Xylan; 8, Starch.

(Park et al. 1997). The hydrolysis pattern of purified enzyme indicated that chitinase from Enterobacter sp. NRG4 was an endochitinase. It exhibited high activity towards swollen chitin, colloidal chitin, regenerated chitin and glycol chitin as compared to flake chitin and crab shell chitin. It showed no activity towards carboxymethyl cellulose, chitosan and Micrococcus lysodeikticus cell wall. The hydrolysis products from swollen chitin were $(\text { GlcNAc })_{2}$ and GlcNAc. Enterobacter sp. G-1 was also reported to secrete an endochitinase which showed high activity towards colloidal chitin and ethylene glycol chitin more than flake chitin or soluble CMC. It could not hydrolyze flake chitosan but showed 36 to $80 \%$ activity towards deacetylated chitosan compared with colloidal chitin. The products from colloidal chitin hydrolysis were mainly (GlcNAc) $)_{2}$ with small amount of $(\mathrm{GlcNAc})_{3}$ and $(\mathrm{GlcNAc})_{4}$ (Park et al. 1997). Characteristics of purified chitinases from other reported Enterobacter spp. are summarized in Table 3. Aeromonas sp. chitinase I and II hydrolyzed colloidal chitin and ethylene glycol chitin effectively but the activity was significantly lower towards chitin and chitosan. No detectable activities towards Micrococcus lysodeikticus cell wall were observed (Ueda and Arai, 1992). Chitinase exhibited a substrate binding capacity of $89.5,26.2$ and $15.2 \%$ for swollen chitin, flake chitin and carboxymethyl cellulose, respectively. Lee et al. (2000) reported binding of Pseudomonas sp. YHS-A2 chitinase $78,12,0,5$ and $10 \%$ with colloidal chitin, chitin, carboxymethyl cellulose, crude chitosan and birch wood xylan, respectively.

Among metal ions, $\mathrm{Mg}^{2+}, \mathrm{K}^{+}$and $\mathrm{Ca}^{2+}$ stimulated chitinase activity by 13,16 and $18 \%$, respectively whereas $\mathrm{Cu}^{2+}$,
$\mathrm{Co}^{2+}, \mathrm{Ag}^{+}$and $\mathrm{Hg}^{2+}$ and inhibited chitinase activity by 9.7 , 15,22 and $72.2 \%$, respectively at $1 \mathrm{mM}$ concentration. Activation of chitinase by $\mathrm{Ca}^{2+}$ or $\mathrm{Mg}^{2+}$ is rare and reported in few cases only. At $100 \mathrm{mM}$ concentration $\mathrm{Cu}^{2+}$ and $\mathrm{Ag}^{+}$ completely inhibited chitinase activity when incubated at room temperature for $1 \mathrm{hr}$. In Pseudomonas aeruginosa, $\mathrm{Mg}^{2+}$ and $\mathrm{Na}^{+}$were inhibitory while $\mathrm{Cu}^{2+}$ activated the chitinase by $50 \%$ (Wang and Chang, 1997). Stimulatory effect of $\mathrm{Ca}^{2+}(30 \%)$ and $\mathrm{Mn}^{2+}(20 \%)$ at $1 \mathrm{mM}$ concentration on Pseudomonas sp. YHS-A2 chitinase has been reported by Lee et al. (2000).

Serratia plymuthica activity was stimulated by 120,150 and $240 \%$ in presence of $10 \mathrm{mM} \mathrm{Ca}^{2+}, \mathrm{Co}^{2+}$ or $\mathrm{Mn}^{2+}$ and inhibited by $80 \%$ in presence of $10 \mathrm{mM} \mathrm{Cu}^{2+}$ (Frankowski et al. 2001). Chitinase from Alcaligenes xylosoxydans was inhibited by $25 \%$ by $\mathrm{Cu}^{2+}$ and $\mathrm{Na}^{+}$at $5 \mathrm{mM}$ but not by $\mathrm{Ca}^{2+}$, $\mathrm{Ba}^{2+}$ or $\mathrm{Mg}^{2+}$ at the same concentration (Vaidya et al. 2003). Enterobacter sp. G-1 chitinase activity was not affected by addition of $\mathrm{Ca}^{2+}$ or $\mathrm{NaCl}$ to the enzyme solution (Park et al. 1997). Chitinase from Enterobacter aerogenes was stimulated by $\mathrm{Zn}^{2+}, \mathrm{Ba}^{2+}, \mathrm{Ca}^{2+}$ and $\mathrm{Mn}^{2+}$ and strongly inhibited by $\mathrm{Hg}^{2+}, \mathrm{Co}^{2+}$ and $\mathrm{Mg}^{2+}$ (Tang et al. 2001). $\mathrm{Hg}^{+}$ and $\mathrm{Hg}^{2+}$ inhibited chitinase of Streptomyces sp. M-20 (Kim et al. 2003). Frankowski et al. (2001) reported stimulation of CHIT60 from Serratia plymuthica HRO-C48 by $10 \mathrm{mM}$ $\mathrm{Ca}^{2+}, \mathrm{Co}^{2+}$ or $\mathrm{Mn}^{2+}$ and inhibition in presence of $\mathrm{Cu}^{2+}$. In contrast, $\mathrm{Mn}^{2+}$ and $\mathrm{Ca}^{2+}$ inhibited chitinase of Bacillus sp. 13.26 (Yuli et al. 2004). $\mathrm{Ag}^{+}$and $\mathrm{Hg}^{2+}$ inhibited chitinase $\mathrm{C} 1$ and $\mathrm{C} 3$ from Vibrio alginolyticus $\mathrm{H}-8$ (Ohishi et al. 1996). $\mathrm{Hg}^{2+}$ also inhibited chitinases from Arthrobacter sp. NHB-10 (Okazaki et al. 1999) and Aeromonas hydrophila 


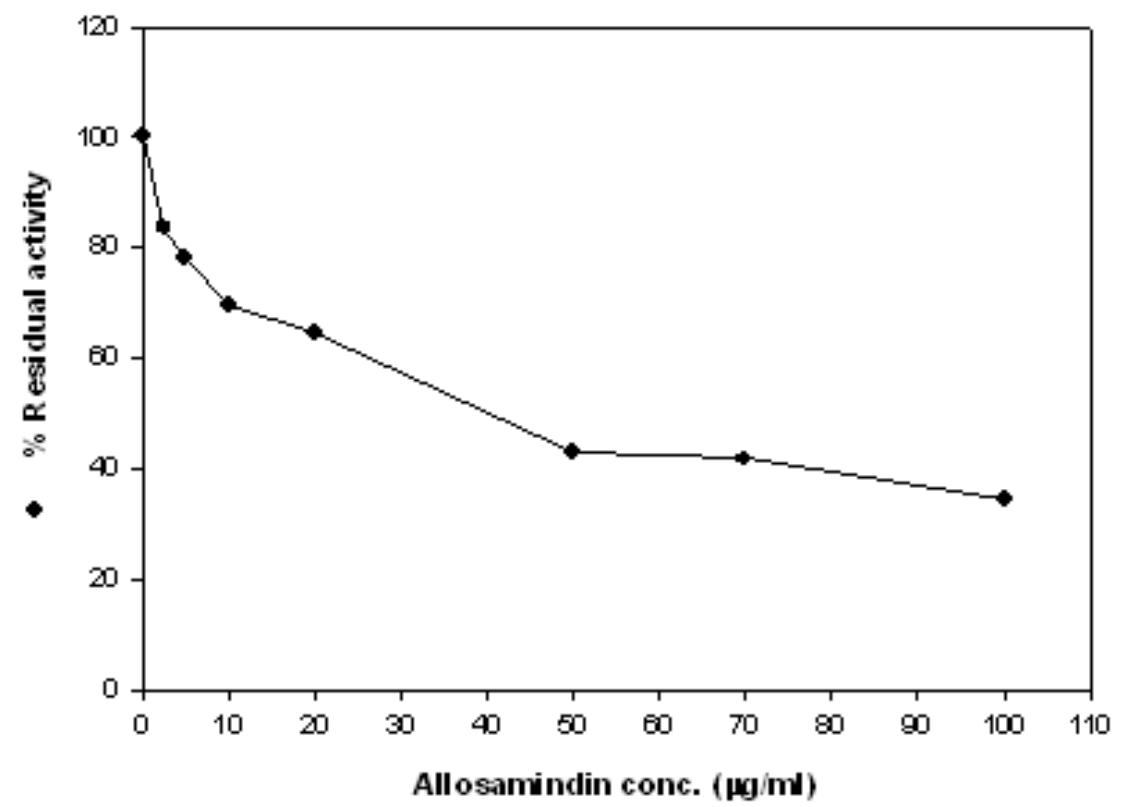

Figure 7. Effect of allosamidin on chitinase from Enterobacter sp. NRG4.

H 2330 (Hiraga et al. 1997). Chitinase from Monascus purpureus CCRC31499 was stimulated by $\mathrm{Fe}^{2+}$ and strongly inhibited by $\mathrm{Hg}^{2+}$ (Wang et al. 2002). $\mathrm{Ag}^{+}$and $\mathrm{Hg}^{2+}$ inhibited chitinase from Ralstonia sp. A-471 (Sutrisno et al. 2004). Enterobacter sp. NRG4 chitinase was inhibited by $11 \%$ in presence of $10 \mathrm{mM}$ EDTA. EDTA at $10 \mathrm{mM}$ concentration inhibited chitinase of Enterobacter sp. G-1 by $42 \%$ (Park et al. 1997).

$\mathrm{N}$-bromosuccinamide at $1 \mathrm{mM}$ and iodoacetamide at $10 \mathrm{mM}$ concentration completely inhibited the enzyme activity. PCMB does not affect the enzyme activity much. DTNB and iodoacetamide inhibition suggested the role of cysteine residues in active site. NBS is protein oxidizing agent. The oxidizing reaction is specific for tryptophan and -SH groups and therefore suggested the role of tryptophan residues. There are few reports in the literature on effect of group specific reagents on chitinase activity. PCMB at $1 \mathrm{mM}$ concentration inhibited chitinase of Enterobacter sp. G-1 by $24 \%$ (Park et al. 1997). PCMB was inhibitory for chitinase of Aeromonas sp. No. 10S-24 (Ueda et al. 1995). Chitinase from Streptomyces sp. M-20 was completely inhibited by PCMB (Kim et al. 2003). Chitinase of Pseudomonas sp. YHS-A2 was inhibited by $90 \%$ in presence of $\mathrm{N}$-bromosuccinimide at $1 \mathrm{mM}$ concentration (Lee et al. 2000).

Allosamidin inhibited chitinase activity by 57.1 and $65.7 \%$ at 50 and $100 \mu \mathrm{g} \mathrm{ml}^{-1}$, respectively. The $\mathrm{IC}_{50}$ value was $40 \mu \mathrm{g} \mathrm{ml}^{-1}(64 \mu \mathrm{M})$. Other reported $\mathrm{IC}_{50}$ values were $48 \mu \mathrm{M}$ for Bacillus sp. BG-11 chitinase (Bhushan and Hoondal, 1999) and $9.0 \mu \mathrm{M}$ for chitinase from human serum and leucocytes (Escott and Adam, 1995).
Among various sugars and end products, chitinase was inhibited by $81.3 \%$ in presence of $\mathrm{N}$-acetyl D-glucosamine at $10 \mathrm{mM}$ concentration whereas glucosamine $\mathrm{HCl}$, galactosamine and glucose inhibited up to $19 \%$. Chitinase of Metarhizium anisopliae was inhibited by 28,21 and 79\% in presence of glucose, $\mathrm{N}$-acetyl D-glucosamine and Dglucosamine, respectively at $10 \mathrm{mM}$ concentration (Pinto et al. 1997).

In conclusion, we have purified and characterized a chitinase from newly isolated Enterobacter sp. NRG4. The capability of this chitinase to hydrolyze chitin efficiently, lower end product inhibition, broad $\mathrm{pH}$ activity and stability makes the enzyme industrially significant for biotechnological applications, especially in production of chitobiose and $\mathrm{N}$-acetyl D-glucosamine.

\section{REFERENCES}

BALSUBRAMANIUM, N.; Juliet, G.A.; SRIKALAIVANI, P. and LALITHAKUMARI, D. Release and regeneration of protoplasts from the fungus Trichothecium roseum. Canadian Journal of Microbiology, April 2003, vol. 49, no. 4, p. 263-268.

BHUSHAN, Bharat and HOONDAL, Gurinder Singh. Effect of fungicides, insecticides and allosamidin on a thermostable chitinase from Bacillus sp. BG-11. World Journal of Microbiology and Biotechnology, June 1999, vol. 15 , no. 3, p. 403-404.

BHUSHAN, Bharat and HOONDAL, Gurinder Singh. Isolation, purification and properties of a thermostable chitinase from an alkalophilic Bacillus sp. BG-11. 
Biotechnology Letters, February 1998, vol. 20, no. 2, p. 157-159.

CHEN, Hsing Chen; HSU, Mei Fang and JIANG, Shann Tzong. Purification and Characterization of an exo-N,N'diacetylchitobiohydrolase like enzyme from Cellulomonas flavigena NTOU1. Enzyme and Microbial Technology, February 1997, vol. 20, no. 3, p. 191-197.

CHERNIN, L.S.; DE LA FUENTE, L.; SOBOLEV, V.; HARAN, S.; VORGIAS, C.E.; OPPENHEIM, A.B. and CHET, I. Molecular cloning, structural analysis, and expression in Escherichia coli of a chitinase gene from Enterobacter agglomerans. Applied Environmental Microbiology, March 1997, vol. 63, no. 3, p. 834-839.

DAHIYA, Neetu; TEWARI, Rupinder; TIWARI, Ram Prakash and HOONDAL, Gurinder Singh. Chitinase production in solid state fermentation by Enterobacter sp. NRG4 using statistical experimental design. Current Microbiology, 2005. In press.

ESCOTT, G.M. and ADAMS, D.J. Chitinase activity in human serum and leucocytes. Infection and Immunity, December 1995, vol. 63, no. 12, p. 4770-4773.

FRANKOWSKI, Jens; LORITO, Matteo; SCALA, Felice; SCHMID, Roland; BERG, Gabriele and BAHL, Hubert. Purification and properties of two chitinolytic enzymes of Serratia plymuthica HRO-C48. Archives of Microbiology, December 2001, vol. 176, no. 6, p. 421-426.

GKARGKAS, Konstantinos; MAMMA, Diomi; NEDEV, George; TOPAKAS, Evangelos; CHRISTAKOPOULOS, Paul; KEKOS, Dimitris and MACRIS, Basil J. Studies on $\mathrm{N}$-acetyl- $\beta$-D-glucosaminidase produced by Fusarium oxysporum F3 grown in solid-state fermentation. Process Biochemistry, July 2004, vol. 39, no. 11, p. 1599-1605.

HIRAGA, Kazumi; SHOU, Lee; KITAZAWA, Mitsunori; TAKAHASHI, Saori; SHIMADA, M.; SATO, R. and ODA, K. Isolation and characterization of chitinase from a flake chitin degrading marine bacterium, Aeromonas hydrophila H-2330. Bioscience Biotechnology and Biochemistry, 1997, vol. 61, no. 1, p. 174-176.

JEUNIAUX, C. Chitinases. In: NEUFELD, E.F. and GINSBURG, V. eds. Complex Carbohydrates. Methods in Enzymology. Academic Press, Inc., New York, 1966, vol. 8, pp. 644-650.

KIM, Kyoung Ja; YANG, Yong Joon and KIM, Jong Gi. Purification and characterization of chitinase from Streptomyces sp. M-20. Journal of Biochemistry and Molecular Biology, 2003, vol. 36, no. 2, p. 185-189.

LAEMMLI, U.K. Cleavage of structural proteins during the assembly of the head of bacteriophage T4. Nature, 1970, vol. 227, p. 680-685.
LEE, H.S.; HAN, D.S.; CHOI, S.W.; KIM, D.S.; BAI, D.H. and YU, J.H. Purification, characterization and primary structure of a chitinase from Pseudomonas sp. YHS-A2. Applied Microbiology and Biotechnology, September 2000, vol. 54, no. 3, p. 397-405.

LOWRY, O.H.; ROSEBROUGH, N.J.; FARR, A.L. and RANDALL, R.J. Protein measurement with Folin phenol reagent. The Journal of Biological Chemistry, 1951, vol. 193 , p. $265-275$.

MATHIVANAN, N.; KABILAN, V. and MURUGESAN, K. Purification, characterization and anti-fungal activity from Fusarium chlamydosporum, a mycoparasite to groundnut rust, Puccinia arachidis. Canadian Journal of Microbiology, July 1998, vol. 44, no. 7, p. 646-651.

MIZUNO, Katsushige; KIMURA, Osamu and TACHIKI, Takashi. Protoplast formation from Schizophyllum commune by a culture filtrate of Bacillus circulans KA-304 grown on a cell-wall preparation of $S$. commune as a carbon source. Bioscience Biotechnology and Biochemistry, 1997, vol. 61 , no. 5, p. 852-857.

MOLANO, Jesús; DURAN, Angel and CABIB, Enrico. A rapid and sensitive assay for chitinase activity using tritiated chitin. Analytical Biochemistry, December 1977, vol. 83, no. 2, p. 648-656.

MONREAL, J. and REESE, E.T. The chitinase of Serratia marcescens. Canadian Journal of Microbiology, 1969, vol. 15, p. 689-696.

OHISHI, Kazuo; YAMAGISHI, Masaoki; OHTA, Toshiya; SUZUKI, Mitsuaki; IZUMIDA, Hitoshi; SANO, Hiroshi; NISHIJIMA, Miyuki and MIWA, Tan. Purification and properties of two chitinases from Vibrio alginolyticus $\mathrm{H}-8$. Journal of Fermentation and Bioengineering, 1996, vol. 82, no. 6, p. 598-600.

OTAKARA, A. Studies on the chitinolytic enzymes of black-koji mold. Part I. Viscometric determination of chitinase activity by application of glycol chitin as a new substrate. Agricultural Biological Chemistry, 1961, vol. 25, p. $50-54$.

OKAZAKI, Katsuichiro; KAWABATA, Toshiyuki; NAKANO, Masahito and HAYAKA, Shigeru. Purification and properties of chitinase from Arthrobacter sp. NHB-10. Bioscience Biotechnology and Biochemistry, 1999, vol. 63, no. 9 , p. 1644-1646.

PARK, Jae Kweon; MORITA, Kenji; FUKUMOTO, Ikuo; YAMASAKI, Yukikazu; NAKAGAWA, Tsuyoshi; KAWAMUKAI, Makoto and MATSUDA, Hideyuki. Purification and characterization of the Chitinase (ChiA) from Enterobacter sp. G-1. Bioscience Biotechnology and Biochemistry, 1997, vol. 61, no. 4, p. 684-689. 
PICHYANGKURA, Rath; KUDAN, Sanya; KULTIYAWONG, Kamontip; SUKWATTANASINITT, Mongkol and AIBA, Sei Ichi. Quantitative production of 2acetamido-2-deoxy-D-glucose from crystalline chitin by bacterial chitinase. Carbohydrate Research, March 2002, vol. 337 , no. 6 , p. 557-559.

PINTO, A. de S., BARRETO, C.C., SCHRANK, A., ULHAO, C.J. and VAINSTEIN, M.H. Purification and characterization of an extracellular chitinase from the entomopathogen Metarhizium anisopliae. Canadian Journal of Microbiology, 1997, vol. 43, no. 4, p. 322-327.

PLEBAN, S.; CHERNIN, L. and CHET, I. Chitinolytic enzymes of an endophytic strain of Bacillus cereus. Letters in Applied Microbiology, September 1997, vol. 25, no. 4, p. 284-288.

REISSIG, Jose L.; STROMINGER, Jack L. and LELOIR, Luis F. A modified colorimetric method for the estimation of N-acetylamino sugars. The Journal of Biological Chemistry, 1955, vol. 217, p. 959-966.

SUTRISNO, A.; UEDA, M.; ABE, Y.; WAKAZAWA, M and MIYATAKE, K. A chitinase with high activity towards partially $\mathrm{N}$-acetylated chitosan from a new, moderately thermophilic chitin degrading bacterium, Ralstonia sp. A471. Applied Microbiology and Biotechnology, January 2004, vol. 63, no. 4, p. 398-406.

TAKAHASHI, Mamoru; TSUKIYAMA, Tadashi and SUZUKI, Tomoo. Purification and some properties of chitinase produced by Vibrio sp. Journal of Fermentation and Bioengineering, 1993, vol. 75, no. 6, p. 457-559.

TANG, Y.; ZHAO, J.; DING, S.; LIU, S. and YANG, Z. Purification and properties of chitinase from Enterobacter aerogenes. Wei Sheng Wu Xue Bao (Acta Microbiologica Sinica), February 2001, vol. 41, no. 1, p. 82-86.

UEDA, M.; FUJIWARA, A.; KAWAGUCHI, T. and ARAI, M. Purification and some properties of six chitinases from Aeromonas sp. No. 10S-24. Bioscience Biotechnology and Biochemistry, 1995, vol. 59, p. 2162-2164.

UEDA, Mitsuhiro and ARAI, Motoo. Purification and some properties of chitinases from Aeromonas sp. No. 10S-24. Bioscience Biotechnology and Biochemistry, 1992, vol. 56, no. 3, p. 460-464.

VAIDYA, R.J.; SHAH, I.M.; VYAS, P.R. and CHHATPAR, H.S. Production of chitinase and its optimization from a novel isolate Alcaligenes xylosoxydans: potential antifungal biocontrol. World Journal of Microbiology and Biotechnology, October 2001, vol. 17, no. 7 , p. 62-69.

VAIDYA, Rajiv; ROY, Satarupa; MACMIL, Simone; GANDHI, Sapan; VYAS, Pranav and CHHATPAR, H.S. Purification and characterization of chitinase from
Alcaligenes xylosoxydans. Biotechnology Letters, May 2003, vol. 25, no. 9, p. 715-717.

VYAS, P.R. and DESHPANDE, M.V. Enzymatic hydrolysis of chitin by Myrothecium verrucaria chitinase complex and its utilization to produce SCP. Journal of General and Applied Microbiology, 1991, vol. 37, no. 3, p. 267-275.

WANG, S.L. and CHANG, W.T. Purification and characterization of two bifunctional chitinases/lysozymes extracellularly produced by Pseudomonas aeruginosa K187 in shrimp and crab shell powder medium. Applied Environmental Microbiology, February 1997, vol. 63, no. 2, p. 380-386.

WANG, San Lang; YEN, Yue Horng; TSIAO, Wei Jen; CHANG, Wen Teish and WANG, Chuan Lu. Production of antimicrobial compounds by Monascus purpureus CCRC31499 using shrimp and crab shell powder as a carbon source. Enzyme and Microbial Technology, August 2002, vol. 31, no. 3, p. 337-344.

WEN, Chih Min; TSENG, Chien Sheng; CHENG, Chih Yu and LI, Yaw Kuen. Purification, characterization and cloning of a chitinase from Bacillus sp. NCTU2. Biotechnology and Applied Biochemistry, June 2002, vol. 35 , no. 3, p. 213-219.

WOO, Cheol Joo and PARK, Heui Dong. An extracellular Bacillus sp. chitinase for the production of chitotriose as a major chitinolytic product. Biotechnology Letters, March 2003, vol. 25, no. 5, p. 409-412.

YAMADA, Hidenori and IMOTO, Taiji. A convenient synthesis of glycol chitin, a substrate of lysozyme. Carbohydrate Research, 1981, vol. 92, no. 1, p. 160-162.

YULI, Purwani E.; SUHARTONO, Maggy Thenawidjaja; RUKAYADI, Yaya; HWANG, Jae Kwan and PYUN, Yu Ryang. Characteristics of thermostable chitinase enymes from the Indonesian Bacillus sp. 13.26. Enzyme and Microbial Technology, 2004, vol. 35, no. 2-3, p. 147-153.

ZHOU, S.N.; YANG, C.Y.; LU, Y.J.; HUANG, L.; CAI, C.U. and LIN, Y. C. Isolation and characterization of chitinase from marine bacterium Vibrio sp. World Journal of Microbiology and Biotechnology, December 1999, vol. 15 , no. 6 , p. $745-746$. 